\title{
CAUSALITY ANALYSIS: ECONOMIC GROWTH, ECONOMIC OPENNESS, ENERGY CONSUMPTION, AND CARBON DIOXIDE EMISSION IN INDONESIA
}

\author{
Azhima Muhammad Fattah \\ Faculty of Economics and Business Diponegoro University \\ Email: azhimafth@students.undip.ac.id (corresponding author) \\ Jaka Aminata \\ Faculty of Economics and Business Diponegoro University \\ Email: jakaaminata@lecturer.undip.ac.id \\ Indah Susilowati \\ Faculty of Economics and Business Diponegoro University \\ Email: indahsusilowati@lecturer.undip.ac.id \\ Arief Pujiyono \\ Faculty of Economics and Business Diponegoro University \\ Email : ariefpujiyono@lecturer.undip.ac.id
}

Received: March 2021; Accepted: April 2021; Available online: July 2021

\begin{abstract}
The purpose of this research is to analyze the causality between economic variables, i.e. economic growth, economic openness, and energy consumption to carbon dioxide emissions, and analyze short-run and long-run connections between research variables in Indonesia during the period 1971 to 2018. This research is using VECM analysis and Granger Causality. The results of the VECM analysis in this research show that in the short-run the variable carbon dioxide emissions in the previous period, economic openness, and energy consumption have a significant effect on carbon dioxide emissions in Indonesia, and in the long run, the variables of economic growth, economic openness, and energy consumption have a significant effect on carbon dioxide emissions in Indonesia. The Granger Causality analysis found bidirectional causality between energy consumption and carbon dioxide emissions. It also found unidirectional causality between economic growth and carbon dioxide emissions. The recommendations that can be shared are that The Government of Indonesia should be more worried about the degradation in environmental quality in Indonesia as a result of economic development. On the other hand, in achieving sustainable economic development, the Indonesian Government must immediately use energy resources more efficiently and environmentally friendly.
\end{abstract}

Keywords : Carbon dioxide emissions; Economic Growth; VECM; Granger Causality.

\begin{abstract}
Abstrak
Riset ini bertujuan untuk menganalisis hubungan sebab akibat antara variabel ekonomi yaitu pertumbuhan ekonomi, keterbukaan ekonomi, serta konsumsi energi terhadap emisi karbon dioksida serta pengaruh jangka pendek dan jangka panjang antara variabel riset di Indonesia sepanjang periode 1971 hingga dengan 2018. Metode yang digunakan dalam riset ini merupakan analisis VECM serta Granger Causality. Hasil dari analisis VECM dalam riset ini membuktikan jika dalam jangka pendek variabel emisi karbon dioksida pada periode sebelumnya, variabel keterbukaan ekonomi, serta variabel konsumsi energi mempengaruhi
\end{abstract}


signifikan terhadap emisi karbon dioksida, dan dalam jangka panjang variabel pertumbuhan ekonomi, keterbukaan ekonomi, serta konsumsi energi mempengaruhi signifikan terhadap emisi karbon dioksida di Indonesia. Dalam analisis Granger Causality ditemui ikatan sebab akibat antara konsumsi energi dan emisi karbon dioksida, dan juga ikatan satu arah antara pertumbuhan ekonomi terhadap emisi karbon dioksida. Bagi pemerintah Indonesia diharapkan dapat lebih memperhatikan tentang penurunan kualitas lingkungan di Indonesia sebagai dampak dari pembangunan ekonomi, di sisi lain, dalam mencapai pembangunan ekonomi yang berkelanjutan, pemerintah Indonesia juga dapat segera melakukan transisi sumber daya energi ke sumber energi yang lebih efisien dan ramah lingkungan.

Kata kunci : Emisi Karbon dioksida; Petumbuhan Ekonomi; VECM, Granger Causality.

How to Cite: Fattah, A. M., Aminata, J., Susilowati, I., \& Pujiyono, A. (2021). Causality Analysis: Economic Growth, Economic Openness, Energy Consumption, and Carbon Dioxide Emission Indonesia. Media Ekonomi dan Manajemen, 36(2), 124-135. doi: http://dx.doi.org/ 10.24856/mem.v36i2.2029.

\section{INTRODUCTION}

In the Environmental Kuznet Curve hypothesis theory, a country's economic growth will be followed by an increase of environmental degradation. In this condition, the impact of the economic growth against the increase of environmental damage will happen continuously, until reaching a certain level of income. When a country has reached a certain level of income, then pollution will experience a decrement (Ula, 2019).

Indonesia is one of the developing countries with continuous increasing economic growth, this can be seen by the continuous growth of Indonesia's GDP per capita annually. However, this economic growth is followed by the increase of the emission of the carbon dioxide each year and, so it affects the degradation of the environmental quality where it fits the EKC hypothesis.

There are some cases that trigger the cause of a relationship between economic growth and the increase in $\mathrm{CO} 2$ emissions each year. First of all, to stimulate its growth, a country needs to increase its economic activities to push its economic growth, where one of the activities is Economic Openness which is reflected through the trade relationship between countries or International Trade. According to (Atici, 2012), trade openness helps to advance in economic development.
However, it can harm the environmental quality of a region as a result of higher levels of production as well as great exploitation of natural energy sources such as coal, oil, and natural gas to meet energy needs. Furthermore, the exploitation of natural energy sources that exceed the limits will cause a variety of losses, such as warming the earth's temperature caused by carbon emissions.

Another problem is Indonesia's energy consumption pattern, where to drive the economic growth, energy consumption is needed in the process to convert raw materials into products and services which benefit the society. Energy as a form of resource has an essential role as the driving force of the economic development in production, distribution up to consumption activities.

This phenomenon is described as "energy ladder". In low income level, energy tends to come from resources that are directly obtained from either biological resource (wood, faeces, sunlight for drying) or human work (also another biological resource, for example, animal). And in higher-income community, processed biofuels, animal power, and some fossil energy are more prominent. Commercial fossil fuel and electricity finally become the most dominant energy resource in the most advanced stage of industrialization and development. Up until 
now, fossil fuel has been one of the most dominant energy resources in terms of global energy demand, including Indonesia. The fossil fuel consumption energy pattern has not changed much, seen from the last few decades (International Energy Agency, 2019). But the world dependency on fossil fuel, including Indonesia, causes a serious impact to the environment. Carbon dioxide which is emitted through the fossil fuel is the main cause of the global warming (Ozturk \& Acaravci, 2010).

On the other hand, Indonesia has quite a few problems regarding the decreasing fossil energy reserve which goes on and is still unable to fully utilize its renewable energy resources. In Indonesia, energy resource is relatively available, but in the long run more alternative energy sources are necessary because of the decreasing oil reserve as the main energy and the necessity to pay attention to the environment in terms of energy consumption to support the economic activities. Few effective ways to resolve those problems are to adopt green technology, increasing energy efficiency, also promoting renewable energy, which is also one of the mechanisms to increase GDP, which drives the industry growth which increases the job opportunities and economic growth. The use of renewable energy will reduce the $\mathrm{CO} 2$ emission, however, its implementation is still hampered by the lack of infrastructure support and limited investment. So, each country needs to develop its potential for renewable energy through raising awareness against environmental sustainability and developing a sustainable industry based on renewable energy. Hence, increased flexibility will increase good socio-economic value (Kumar, 2016; Sasana \& Aminata, 2019).

Based on the elaboration above, economic growth is considered to have an effect on the increase of the $\mathrm{CO}_{2}$ emission in Indonesia, and this is caused by economic activity and also energy problem in Indonesia. Therefore, the authors are interested in conducting similar research and continuing the previous research, hence, in this thesis research the authors choose the title "Causality Analysis: Economic Growth, Economic Openness, Energy Consumption, And Carbon Dioxide Emission In Indonesia"

\section{LITERATURE REVIEW}

\section{The Relationship Between Economic Growth and Environmental Degra- dation}

In principle, economic growth and the environment are related to each other, it can be seen through the Kuznet environmental curve. Simon Kuznets, Nobel laureate in 1955, made a hypothesis known as the Environmental Kuznets Curve. This theory explains the relationship between economic growth and the decline or environmental degradation. In the Kuznetz curve, it is also explained that the level of environmental pollution or degradation will increase and then experience a decrease or a turning point at a certain income level. The decrease in the level of pollution is in accordance with the increase in people's income (Todaro \& Smith, 2012).

Based on the EKC hypothesis, environmental damage is likely to occur in developing countries because these countries tend to have low per capita income. This is because in the early stage of growth, industrialization focused on how to grow the economy rapidly ignoring environmental issues. In this phase, there is a positive correlation between environmental degradation and economic growth because there are many pollutants in the air resulting from the raising economic growth. However, at a certain level of income, a turning point takes place. In this phase, awareness of the importance of environmental quality has begun to develop and progress, generally this phase occurs in developed countries that are trying to reduce emissions by 
applying environmentally friendly technology (Rifai, 2017).

\section{The Relationship Between Economic Openness and Environmental Degradation}

In several research, Copeland and Taylor's Pollution Haven Hypothesis, in 1994, found in their research entitled North-South Trade and the Environment, it is explained the effect of trade on the environment. In their hypothesis, they state that when trade is liberalized, large industries that cause pollution are likely to shift from developed countries with strict environmental regulations to poor or developing countries with weak environmental regulations $\mathrm{On}$ the other hand, industries that are less polluting will tend to migrate to developed countries. The underlying assumption is that environmental regulation will increase costs, which in turn makes the exports of highly regulated countries relatively more expensive than those of less strict regulations (Sun, Clottey, Geng, \& Fang, 2019).

\section{The Relationship between Energy consumption and Environmental Degradation}

In the economic field, the environment is seen as a composite asset that provides a variety of services. The environment is a special asset because it provides a source of energy that can be used in the economic activities of people but is seen as a fixed asset. As with any other asset, the energy use would likely be increased, or at least preventing depreciation that shouldn't happen. Energy is used in the economy as raw material, which is converted into consumers' products by the production process, and energy is transformed as fuel (Tietenberg \& Lewis, 2015).

\section{The Relationship Between Energy Consumption and Economic Openness}

Energy consumption is considered to be related to the development of trade openness activities. In regards to this issue, several researchers have found evidence related to the influence of trade openness on energy consumption in a country or a panel of several countries. According to the research of (Abidin, Haseeb, Azam, \& Islam, 2015) and (Saboori \& Sulaiman, 2013), there is evidence that increased trade openness activities had a significant impact on energy consumption growth in Malaysia. The research, (Shahbaz, Hye, Tiwari, \& Leitão, 2013), also reveals that trade openness is closely related to energy consumption in China. According to research, (Nasreen \& Anwar, 2014) with the FMOLS and DOLS estimated models showed a positive relationship between energy consumption and trade openness. In the analysis of the causal relationship, have found there is a causal relationship between trade openness and energy consumption in Asian countries.

\section{The Relationship Between Energy Consumption and Economic Growth}

The relationship between economic growth and energy consumption can be explained through the Augmented Solow Growth Model approach. This model is a development from the economic growth model created by Robert Solow (1956). Based on the research from (Wang, 2013) in the Augmented Solow Growth Model, energy is sometimes classified as natural resources, being one of the inputs that determines the amount of the output produced, and is modelled as follows:

$y=(1-y) K^{\beta} L^{1-\beta}+y E, 0<y<1,0<\beta<1 \ldots$ (1)
$k=s(Y-E)-\delta K, 0<s<1,0<\delta<1 \ldots \ldots \ldots \ldots \ldots . .(2)$

Equation (1) follows the Cobb-Douglas function with labor $(L)$, capital $(K)$ and energy $(E)$ as independent variables of output $(Y) . \beta$ is a parameter that describes the proportion of input $K$ in production. Meanwhile $y$ is a parameter which explains the proportion of input $E$ in production. Equation (2) $k$ shows the rate 
of capital growth which refers to the level of investment, $s$ is the rate of savings, $\delta$ shows the level of depreciated capital and $s(Y-E)$ shows the accumulation of adjusted capital for energy consumption (Rifai, 2017).

\section{The Relationship Between Economic Growth and Economic Openness}

Through economic openness, developing countries will increase productivity and efficiency by utilizing new technologies that will lead to increased production. According to the endogenous growth theory, as emphasized by Grossman and Helpman (1992) and Harrison (1996), if a country's trade openness increases, the number of imported goods and service will also increase. These goods and services contain advanced technology from other countries. Therefore, domestic companies can learn advanced technology from other countries so that they can improve national technology. International trade can boost a country's economic growth (Herawati, 2016)

\section{Research Hypothesis}

The research hypothesis is constructed based on theory and previous research which is a temporary answer to the formulation of the problem. The hypothesis consists of the null hypothesis (0) and the alternative hypothesis (a) which has two possibilities, whether it is accepted or rejected if there is a deviation from the previous facts. By using the State of Indonesia as a research object because Indonesia is a developing country with fairly rapid economic growth by conducting international trading activities and on the other hand also observing the concept of environmental sustainability. Based on the conceptions that have been formed, the hypotheses that can be formulated in this study are as follows:
H1: In the long and short term, trade has a positive and significant impact on the level of carbon dioxide emissions and economic growth in Indonesia.

$\mathrm{H} 2$ : In the long and short term, energy consumption has a positive and significant impact on the level of carbon dioxide emissions and economic growth in Indonesia.

H3: There is a causal relationship between economic growth and carbon dioxide emissions, trade and carbon dioxide emissions, as well as energy consumption and carbon dioxide emissions in Indonesia.

\section{RESEARCH METHOD}

This research is a descriptive quantitative research. The data type used in this research is secondary data. The data is a time series data. The time series data used in this research are annual data from 1971-2018. The secondary data collected in this research comes from the World Development Indicator, International Energy Agency, Ministry of Energy and Mineral Resources, literature study which is done by studying theories from books by conducting analysis which is in accordance to this research and other sources which support this research

Variables which are used in this research are categorized into two types which are dependent variable and independent variables.

The dependent variable used in this research is the emission of the carbon dioxide in Indonesia. And the independent variables used in this research are the Economic Growth data, Economic Openness data, and Energy Consumption data.

The methods which are used in this research are Vector Error Correction Model (VECM) and Granger Causality. VECM is a restricted VAR model which is used for non-stationary variables but has a potential to be co-integrated. Causality study is intended for measuring the 
strength of the relationship between variables and indicates the direction of the relationship which are $\mathrm{X}$ causes $\mathrm{Y}, \mathrm{Y}$ causes $\mathrm{X}$, or $\mathrm{X}$ causes $\mathrm{Y}$ and $\mathrm{Y}$ causes $\mathrm{X}$.

Here are the estimation model used in this research referring to the model of Firdaus (2011) in the equation and also the research of Rifai (2017), Shahbaz et al. (2013) dan Budiwan (2020):

$\Delta \ln G D P_{t}=\propto_{0}+\sum_{i=1}^{p}$ ai $\Delta \ln G D P_{t-1}+$ $\sum_{i=1}^{p}$ bi $\Delta \ln T R D_{t-1}+$

$\sum_{i=1}^{p}$ bi $\Delta \ln E U S_{t-1}+$

$\sum_{i=1}^{p}$ bi $\Delta \ln \mathrm{CO}_{t-1}+e_{t}$

$\Delta \ln T R D_{t}=\propto_{0}+\sum_{i=1}^{p}$ ai $\Delta \ln T R D_{t-1}+$

$\sum_{i=1}^{p}$ bi $\Delta \ln G D P_{t-1}+$

$\sum_{i=1}^{p}$ ai $\Delta \ln E U S_{t-1}+$

$\sum_{i=1}^{p}$ bi $\Delta \ln \mathrm{CO}_{t-1}+e_{t}$

$\Delta \ln E U S_{t}=\propto_{0}+\sum_{i=1}^{p}$ ai $\Delta \ln E U S_{t-1}+$

$\sum_{i=1}^{p}$ bi $\Delta \ln G D P_{t-1}+$

$\sum_{i=1}^{p}$ ai $\Delta \ln T R D_{t-1}+$

$\sum_{i=1}^{p}$ bi $\Delta \ln \mathrm{CO}_{t-1}+e_{t}$

$\Delta \ln C O 2_{t}=\propto_{0}+\sum_{i=1}^{p}$ ai $\Delta \ln C O 2_{t-1}+$

$\sum_{i=1}^{p}$ bi $\Delta \ln G D P_{t-1}+$

$\sum_{i=1}^{p}$ ai $\Delta \ln T R D_{t-1}+$

$\sum_{i=1}^{p}$ bi $\Delta \ln E U S_{t-1}+e_{t}$

Description:

$\mathrm{GDP}_{t}=$ GDP per capita based on the year 2010 (US\$)

$\mathrm{TRD}_{\mathrm{t}}=$ Percentage of the trading rate from total GDP

EUS $_{\mathrm{t}}=$ Energy consumption per capita

$\mathrm{CO} 2_{\mathrm{t}}=$ Carbon dioxide emission per ton

\section{RESULT AND ELABORATION}

\section{The Result of The Stationarity Test}

Depend on the results of the Augmented Dicky Fuller (ADF) test, it can be inferred that unit roots are present at zero order (level) or not stationary at zero order in CO2, GDP and EU variables and only the TRD variable is stationary at zero order (level). It indicates that all variables are stationary in the first order (first difference) after differentiation is formed to the results, this can be shown by seeing the t-statistic is greater than the Critical
Value $(5 \%)$ for each of the variables, This implies rejecting the null hypothesis $\mathrm{H} 0$, which implies that no unit root is already stationary for the series or the results. It can be assumed that the four variables, that is per capita GDP, economic openness, energy consumption and per capita Carbon emissions, are stationary in their first differential form (Table 1).

\section{The Result of The Optimal Lag Length Test}

In this research, the lag length will be determined by looking at the value of Likelihood Ratio (LR), Final Prediction Error (FPE), Akaike Information Criteria (AIC), Schwarz Information Criterion (SIC), and Hannan Quinn Criteria (HQC). The value that is selected is the smallest value of LR, FPE, AIC, SIC, and HQC. The result between the 0 lag and the $7^{\text {th }}$ lag shows that the smallest result is the $7^{\text {th }}$ lag. Determining the $7^{\text {th }}$ lag as the optimal lag is based on the result of the Eviews where the $7^{\text {th }}$ lag possessed the most stars. This shows that with a confidence interval of $95 \%$, the optimal lag is the $7^{\text {th }}$ lag (Table 2).

\section{The Result of The Cointegration}

This test uses the cointegration test developed by Johansen. Johansen test uses trace statistics analysis and critical value at significance level $=5 \%, \mathrm{H} 1$ is accepted if trace statistics value is bigger than the critical value at the significance level $=$ $5 \%$.

It can be explained that in the test with $5 \%$ (0.05) significance level, the $\mathrm{CO} 2$ emission, GDP, TRD and EU variables are cointegrated. It can be proven by a bigger trace value than the critical value which is 0.05 . It means $\mathrm{H} 0$ is rejected and $\mathrm{H} 1$ is accepted or in other words, the variables used in this research are cointegrated one another with a total of 3 cointegrated. Therefore, the VECM estimation technique can be used in this research (Table 3). 


\section{Vecm Estimation Result (Vector Error Correction Model)}

The use of VECM estimation model is in accordance with the formulation of the problem in this research, that is to test the short-term and long-term relationships between carbon dioxide emission and the factors that influence it, which are the variables of Economic Growth, Economic Openness and Energy Consumption.

In order to find out whether the research variables are influential or not, it can be determined by comparing the t-statistical value of the estimation results against the table. The t-table value for observation with $\mathrm{n}=43$ and a $5 \%$ significance is 1.68107 .

The equation of the cumulative emission of carbon dioxide as the dependent variable and the emission of carbon dioxide from the previous time as the independent variable in the VECM estimation for the short-term estimate indicates that there are five factors that have a major impact on the emission of carbon dioxide. In the second lag, third lag, fifth lag, sixth lag and seventh lag, these five factors are carbon emission variables, which have a positive and major effect on the carbon dioxide emission variable. This can be shown by the t-statistical values (2.38966), (2.08122), (4.31317), (2.75176) and (3.91246), which are greater than the value of the t-table, that is (1.68023).

The analysis of carbon dioxide emissions as the dependent variable and the economic openness variable as the independent variable in the VECM estimation for the short-term estimate shows that there is one variable that has a major impact on carbon dioxide emissions. The seventh lag economic openness variable is one of those variables, which has a negative and major effect on variable carbon dioxide emission. This can be shown, as follows, by the t-statistic value ($1.71505)$, which is greater than the t-table value, that is (1.68023).
The equation for the variable carbon dioxide emission as the dependent variable and energy consumption as the independent variable in the VECM calculation for the short-term indicates that there are two factors that have a major effect on the emission of carbon dioxide. The two variables are the sixth lag and the seventh lag energy consumption variable, which have a positive and major effect on the carbon dioxide emission variable. This can be shown by the t-statistical value, which is greater than the t-table value (1.71698) and (3.09079), which is greater than the t-table value, which is (1.68023).

The long-term result of the VECM estimation indicates that the GDP variable has a positive and major effect with a coefficient value of 2.45 on carbon dioxide emissions. This can be shown by the tstatistic value, which is (2.43017) which is greater than the value of the t-table, which is (1.68023). And economic growth only has a major long-term impact on total emission of carbon dioxide.

The long-term result of the VECM estimation indicates that the TRD variable has a positive and major effect on carbon emissions, with a coefficient of 4.03. This can be shown by the t-statistic value, which is (5.29035) which is higher than the value of the t-table, which is (1.68023). And economic openness, both in the long and short term, has a major impact on total carbon dioxide emissions.

And the long-term result of the VECM estimation for the EU variable has a positive and major effect on the emission of carbon dioxide, with a coefficient value of 4.26. This can be shown by the tstatistical value, which is (3.11708) and is greater than the value of the t-table, that is (1.68023). And energy consumption has a major effect, both in the long and short term, on the amount of carbon dioxide released.

The VECM estimation result for the short and long term above are valid results 
where, it is known the R-squared determination coefficient value is 0.93 of 1.00 or $93 \%$ of 100 percent where, the change in the dependent variable (carbon dioxide emission) can be explained by the independent variables (economic growth, economic openness, and energy consumption) of $93 \%$ from a maximum of $100 \%$.

\section{Impulse Response Function (IRF) Analysis}

Based on the result of the IRF (Impulse Response Function) analysis, it can be concluded that the response of $\mathrm{CO} 2$ emission to the $\mathrm{CO} 2$ shock itself in the 1 st to 7 th periods tends to show negative trend, but there is a spike in the 8th to the $10^{\text {th }}$ period which shows a positive trend. The response of $\mathrm{CO} 2$ emission to the shock GDP per capita tends to fluctuate, in the 1st to 10th periods, and tends to show a positive trend. The response of $\mathrm{CO} 2$ emission to the Trade shock tends to fluctuate from the 1st to 10th periods and shows a negative trend. The response of $\mathrm{CO} 2$ emission to the EU shock (energy consumption) in the 1st to 6th period shows a positive trend. However, there is a surge in the 7 th to 10th period which showed a negative trend (Figure 1).

\section{Forecast Error Variance Decomposition (FEVD) Analysis}

In the 1st period, it is explained that carbon dioxide emission was greatly affected by the shock of carbon dioxide emissions itself by 100 percent. Meanwhile, in the 1st period, the variables economic growth, economic openness, and energy consumption haven't had an effect on carbon dioxide emission. Furthermore, from period 1 to period 10, the proportion of shock carbon dioxide emissions itself still has the greatest influence (Table 4).

\section{The Result of the Granger Causality Test}

In the Granger Causality test, a causal relationship is found between the energy consumption variables and $\mathrm{CO} 2$ emissions per capita in the research. This is in accordance with the research hypothesis and previous research, according to research (Hwang \& Yoo, 2014) and (Tietenberg \& Lewis, 2015), energy sources are sometimes classified as natural resources and are used as one of the inputs that determine the amount of output which is produced, and the energy that is transformed as fuel, which eventually, the raw materials and the energy return to the environment as waste products. This study also finds a unidirectional causality relationship between the variable GDPs per capita and $\mathrm{CO} 2$ emissions per capita.

Table 1. The Result of the Stationarity Test

\begin{tabular}{lllll}
\hline \multirow{2}{*}{ Variabel } & \multicolumn{2}{c}{ Level } & \multicolumn{2}{c}{$\mathbf{1}^{\text {st }}$ Difference } \\
\cline { 2 - 5 } & ADF & CV (5\%) & ADF & CV (5\%) \\
\hline LNCO2 & 0.44 & -2.92 & -7.97 & -2.92 \\
LNGDP & -0.68 & -2.92 & -5.07 & -2.92 \\
LNTRD & -3.45 & -2.92 & -8.88 & -2.92 \\
LNEU & -1.13 & -2.92 & -6.20 & -2.92 \\
\hline \multicolumn{3}{c}{ Source: Eviews 10, (processed) }
\end{tabular}


Table 2. The Result of the Optimal Lag Length Test

\begin{tabular}{ccccccc}
\hline Lag & LogL & LR & FPE & AIC & SC & HQC \\
\hline $\mathbf{0}$ & 197.8215 & NA & $7.27 \mathrm{e}-10 *$ & -9.691075 & $-9.522187 *$ & -8.228739 \\
$\mathbf{1}$ & 209.2934 & 20.07587 & $9.16 \mathrm{e}-10$ & -9.464672 & -8.620232 & -9.159349 \\
$\mathbf{2}$ & 226.3771 & 20.40089 & $8.91 \mathrm{e}-10$ & -9.518857 & -7.998865 & -8.969276 \\
$\mathbf{3}$ & 234.6093 & 11.11341 & $1.40 \mathrm{e}-09$ & -9.130465 & -6.934921 & -8.336625 \\
$\mathbf{4}$ & 244.6894 & 11.59208 & $2.15 \mathrm{e}-09$ & -8.834468 & -5.963373 & -7.796371 \\
$\mathbf{5}$ & 259.3455 & 13.92331 & $2.92 \mathrm{e}-09$ & -8.767274 & -5.220627 & -7.484918 \\
$\mathbf{6}$ & 278.8997 & 14.66567 & $3.64 \mathrm{e}-09$ & -8.944985 & -4.722786 & -7.418371 \\
$\mathbf{7}$ & 315.9922 & $\mathbf{2 6 . 4 7 9 7 4} *$ & $2.50 \mathrm{e}-09$ & $\mathbf{- 9 . 9 9 9 6 1 1 *}$ & -5.101861 & $\mathbf{- 9 . 6 3 0 0 1 1 *}$ \\
\hline
\end{tabular}

Source: Eviews 10, (processed)

Table 3. The Result of the Cointegration Test

\begin{tabular}{lcclc}
\hline $\begin{array}{c}\text { Hypothesized } \\
\text { No. of CE(s) }\end{array}$ & $\begin{array}{c}\text { Eigen } \\
\text { value }\end{array}$ & $\begin{array}{c}\text { Trace } \\
\text { Statistic }\end{array}$ & $\begin{array}{l}\text { Critical Value } \\
\mathbf{0 . 0 5}\end{array}$ & $\begin{array}{l}\text { Prob. } \\
* *\end{array}$ \\
\hline None $*$ & 0.76 & $\mathbf{9 1 . 3 6}$ & $\mathbf{4 0 . 1 7}$ & 0.00 \\
At most 1 $*$ & 0.42 & $\mathbf{3 5 . 0 9}$ & $\mathbf{2 4 . 2 7}$ & 0.00 \\
At most 2 $*$ & 0.28 & $\mathbf{1 3 . 1 9}$ & $\mathbf{1 2 . 3 2}$ & 0.03 \\
At most 3 & 0.00 & 0.28 & 4.129 & 0.65 \\
\hline
\end{tabular}

Source: Eviews 10, (processed)

Table 4. The Forecast Error Variance Decomposition Analysis

\begin{tabular}{cccccc}
\hline \multicolumn{6}{l}{ Variance Decomposition of D(CO2): } \\
\hline Period & S.E. & D(LNCO2) & D(LNGDP) & D(LNTRD) & D(LNEU) \\
\hline $\mathbf{1}$ & 0.112197 & 100.0000 & 0.000000 & 0.000000 & 0.000000 \\
$\mathbf{2}$ & 0.126139 & 85.33603 & 8.439165 & 2.410410 & 3.814395 \\
$\mathbf{3}$ & 0.163739 & 68.86112 & 15.74174 & 1.559205 & 13.83793 \\
$\mathbf{4}$ & 0.170430 & 70.50778 & 14.63356 & 1.447884 & 13.41077 \\
$\mathbf{5}$ & 0.175649 & 66.82670 & 13.77707 & 2.821589 & 16.57464 \\
$\mathbf{6}$ & 0.188611 & 66.78501 & 14.61831 & 3.417781 & 15.17890 \\
$\mathbf{7}$ & 0.214198 & 55.63526 & 13.57187 & 3.559021 & 27.23385 \\
$\mathbf{8}$ & 0.215955 & 54.80439 & 13.36095 & 4.438323 & 27.39634 \\
$\mathbf{9}$ & 0.302813 & 67.93017 & 7.517103 & 2.927303 & 21.62543 \\
$\mathbf{1 0}$ & 0.315720 & 66.20672 & 7.234358 & 5.569955 & 20.98897 \\
\hline
\end{tabular}

Source: Eviews 10, (processed)

Table 5. The Granger Causality Analysis

\begin{tabular}{lccc}
\hline \multicolumn{1}{c}{ Null Hypothesis : } & Obs & F-Statistic & F-Statistic \\
\hline LNGDP does not Granger Cause LNCO2 & 41 & 7.75 & 0.00 \\
LNEU does not Granger Cause LNCO2 & 41 & 5.13 & 0.02 \\
LNCO2 does not Granger Cause LNEU & 41 & 4.3 & 0.03 \\
\hline
\end{tabular}

Source: Eviews 10, (processed) 


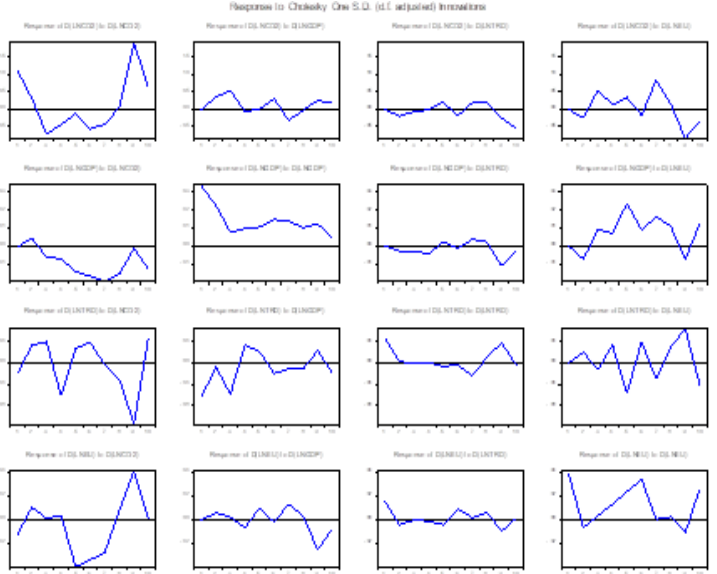

Figure 1. Impulse Response Function Analysis Source: Eviews 10, (processed)

\section{CONCLUSION AND RECOMMEN- DATION}

In this research, a causal relationship is found in the Granger Causality test between the variables of energy consumption and $\mathrm{CO} 2$ emissions per capita. This is in compliance with the hypothesis of research and previous research. This research also identifies a unidirectional of causality relationship between per capita variable GDPs and per capita variable $\mathrm{CO} 2$ emissions. In the VECM (Vector Error Correction Model) test, it is shown that the short-term variable, the $\mathrm{CO} 2$ emission previous period, economic openness and energy use have shown a major impact in Indonesia over the period 1971-2018 on the carbon $\mathrm{CO} 2$ emission variable of the current year. In the long term, economic growth, economic openness and energy consumption have shown a major impact on Indonesia's $\mathrm{CO} 2$ emission variables over the period 1971-2018. The response of $\mathrm{CO} 2$ emissions to the shock variable of $\mathrm{CO} 2$ emissions itself, GDP per capita, trade and EU (energy consumption) varies with the $\mathrm{CO} 2$ emissions in Indonesia during the period 1971-2018, based on the results of the IRF test. The highest contribution to $\mathrm{CO} 2$ emissions in Indonesia, based on the research findings of the VDC test, is the $\mathrm{CO} 2$ emission itself, which contributed 66.20 percent until the end of the period.
The recommendations that can be shared are that The Government of Indonesia should be more worried about the degradation in environmental quality in Indonesia as a result of economic development. On the other hand, in achieving sustainable economic development, the Indonesian Government must immediately use energy resources more efficiently and environmentally friendly because the use of fossil energy sources which still dominates the demand for national energy consumption to produce economic output is the biggest factor causing high levels of carbon dioxide emissions. As well as the Indonesian Government is expected to improve policies that regulate environmental quality improvement, because the existence of good policies can be a foundation for achieving targets in achieving improvement in the quality of the national environment.

\section{REFERENCES}

Abidin, I. S. Z., Haseeb, M., Azam, M., \& Islam, R. (2015). Foreign direct investment, financial development, international trade and energy consumption: Panel data evidence from selected ASEAN countries. International Journal of Energy Economics and Policy, 5(3), 841-850. 
Budiwan, I. (2020). Analisis Pengaruh Konsumsi Energi Terhadap Pertumbuhan Ekonomi dan Emisi Karbon Dioksida. Bogor: Bogor Agricultural University (IPB).

Firdaus, M. (2011). Aplikasi Ekonometrika untuk Data Panel dan Time Series. Bogor: IPB Press.

Herawati, W. (2016). Analisis Pengaruh Keterbukaan Ekonomi terhadap Pertumbuhan Ekonomi di Indonesia Tahun 1980-2013. (June), 4-13.

Hwang, J. H., \& Yoo, S. H. (2014). Energy consumption, $\mathrm{CO} 2$ emissions, and economic growth: Evidence from Indonesia. Quality and Quantity, 48(1), 63-73. https://doi.org/10.1007/s11135-0129749-5

International Energy Agency (IEA). (2019). Southeast Asia Energy Outlook 2019 - Analysis. Iea, (October).

Kumar, S. (2016). Assessment of renewables for energy security and carbon mitigation in Southeast Asia: The case of Indonesia and Thailand. Applied Energy, 163, 63-70. https://doi.org/10.1016/j.apenergy.201 5.11 .019

Nasreen, S., \& Anwar, S. (2014). Causal relationship between trade openness, economic growth and energy consumption: A panel data analysis of Asian countries. Energy Policy, 69(June), 82-91. https://doi.org/10.1016/j.enpol.2014.0 2.009

Ozturk, I., \& Acaravci, A. (2010). CO2 emissions, energy consumption and economic growth in Turkey. Renewable and Sustainable Energy Reviews, 14(9), 3220-3225. https://doi.org/10.1016/j.rser.2010.07. 005
Rifai, M. A. (2017). Analisis hubungan kausalitas antara pertumbuhan ekonomi, konsumsi energi dan emisi karbon dioksida di 4 negara asean. Bogor: Bogor Agricultural University (IPB).

Saboori, B., \& Sulaiman, J. (2013). CO2 emissions, energy consumption and economic growth in association of Southeast Asian Nations (ASEAN) countries: Acointegration approach. Energy, 55, 813-822. https://doi.org/10.1016/j.energy.2013. 04.038

Sasana, H., \& Aminata, J. (2019). Energy subsidy, energy consumption, economic growth, and carbon dioxide emission: Indonesian case studies. International Journal of Energy Economics and Policy, 9(2), 117-122. https://doi.org/10.32479/ijeep.7479

Shahbaz, M., Hye, Q. M. A., Tiwari, A. K., \& Leitão, N. C. (2013). Economic growth, energy consumption, financial development, international trade and $\mathrm{CO} 2$ emissions in Indonesia. Renewable and Sustainable Energy Reviews, 25, 109121. https://doi.org/10.1016/j.rser.2013.04. 009

Sun, H., Clottey, S. A., Geng, Y., \& Fang, K. (2019). Trade Openness and Carbon Emissions: Evidence from Belt and Road Countries. 1-20.

Tietenberg, T. H., \& Lewis, L. (2015). Environmental \& Natural Resource Economics (10th editi). Boston: Pearson.

Todaro, M., \& Smith, S. C. (2012). Economic Development, 11th Edition. In Economic Development (11th Editi). New York: Pearson.

Ula, T. (2019). Analisis Dampak Diversifikasi Ekspor Produk Dan Pertumbuhan Ekonomi Terhadap Lingkungan: Studi Indonesia. Journal of Economics Science, 5(2), 35-45. 
Wang, D. (2013). Munich Personal RePEc Archive A Dynamic Optimization on Energy Efficiency in Developing Countries A Dynamic Optimization on Energy Efficiency in Developing. (43749). 